\title{
Hop stunt viroid detection in hops (Humulus lupulus) in Australia
}

\author{
G. A. Chambers ${ }^{1}$ (I) $\cdot$ K. Dodds ${ }^{2} \cdot$ N. J. Donovan ${ }^{1}$
}

Received: 15 October 2020 / Accepted: 17 January 2021 / Published online: 17 February 2021

(c) Australasian Plant Pathology Society Inc. 2021

\begin{abstract}
Hop stunt viroid (HSVd), a significant pathogen of some hop cultivars, was detected for the first time in hops in Australia. Plants were tested for graft-transmissible pathogens prior to their use in research trials. Upon observing symptoms indicative of potential viroid infection, RNA was extracted and amplified using reverse transcription polymerase chain reaction (RT-PCR); HSVd identity was confirmed by sequencing.
\end{abstract}

Keywords Hops $\cdot$ Australia $\cdot$ Hostuviroid $\cdot$ RT-PCR

Hop stunt viroid (HSVd) is found in the Hostuviroid genus of the Pospiviroidae family and has a wide host range including citrus (Citrus sp.), grape (Vitis sp.), apricot (Prunus armeniaca), plum (Prunus sp.), almond (Prunus dulcis) and hops (Humulus lupulus) (Eastwell and Sano 2009). HSVd has previously been reported in hops in Japan, Korea, United States, China and Slovenia (Sasaki and Shikata 1977; Lee et al. 1990; Eastwell and Nelson 2007; Guo et al. 2008; Radisek 2012). In Australia, HSVd has only been reported in citrus (Gillings et al. 1991), where symptomatic and symptomless variants were observed, grape (Koltunow et al. 1988) and various Prunus species (Kinoti et al. 2020).

Hop cultivation has taken place in Australia for more than 100 years, with an estimated 700 hectares planted (IHGC 2020). Several viruses and viroids infect hops in Australia including American hop latent virus (Dann et al. 2014), hop latent virus, hop mosaic virus (Munroe 1987), apple mosaic virus (Crowle et al. 2003) and hop latent viroid (Crowle 2010). Hop rhizomes of various cultivars were sourced from New South Wales and grown in pots in a controlled environment greenhouse maintained at $25^{\circ} \mathrm{C}$. Symptoms of chlorosis, downward facing curled leaves and distorted leaf growth were observed (Fig. 1) on one plant of cultivar Cascade. These symptoms are typical of viroid infection,

G. A. Chambers

grant.chambers@dpi.nsw.gov.au

1 New South Wales Department of Primary Industries (NSW DPI), Elizabeth Macarthur Agricultural Institute, Menangle, NSW 2568, Australia

2 NSW DPI, Tumut, NSW 2720, Australia therefore leaf samples from this plant were collected for testing 18 days after planting. RNA was extracted from the leaf blade using an Isolate II RNA plant kit (Bioline, Meridian Bioscience). HSVd was detected via RT-PCR using primers HSVd-F/HSVd-R (Wang et al. 2009) and was subsequently confirmed with primer sets HSVd-F1/ HSVd-R1 (Bernad and Durán Vila 2006) and HSVdRTR-F/HSVd-RTR-R (Lin et al. 2015). Control extracts were isolated from an uninfected hop plant and a citrus plant infected with HSVd.

The purified DNA amplification products generated using the primers described by Lin et al. (2015) and Wang et al. (2009), were bidirectionally sequenced and aligned using Geneious Prime (version 2020.1.2, Biomatters, Auckland, New Zealand) to produce a consensus sequence. BLASTn analysis of the 299-nucleotide consensus sequence (R2) determined that the viroid present had $99 \%$ similarity to HSVd isolates found in hops in Japan and China (GenBank accessions AB039271 and EU365356) and was not similar to isolates that induce cachexia in citrus. The consensus sequence was deposited in GenBank (accession MW015998). HSVd was also detected in leaf samples collected from 2 symptomatic (cv Cascade) field plants growing in NSW using HSVd-F/HSVd-R primers, sequencing showed 100\% similarity between the two field isolates and $100 \%$ similarity to the R2 isolate consensus sequence. Sequence data from a representative of the field isolates ( $\mathrm{ft} 1$ ) was submitted to GenBank (accession MW280148).

In reporting the detection of HSVd in grape, Koltunow et al. (1988) suggested that transmission was possible from grape to hops in regions of southern Australia where 


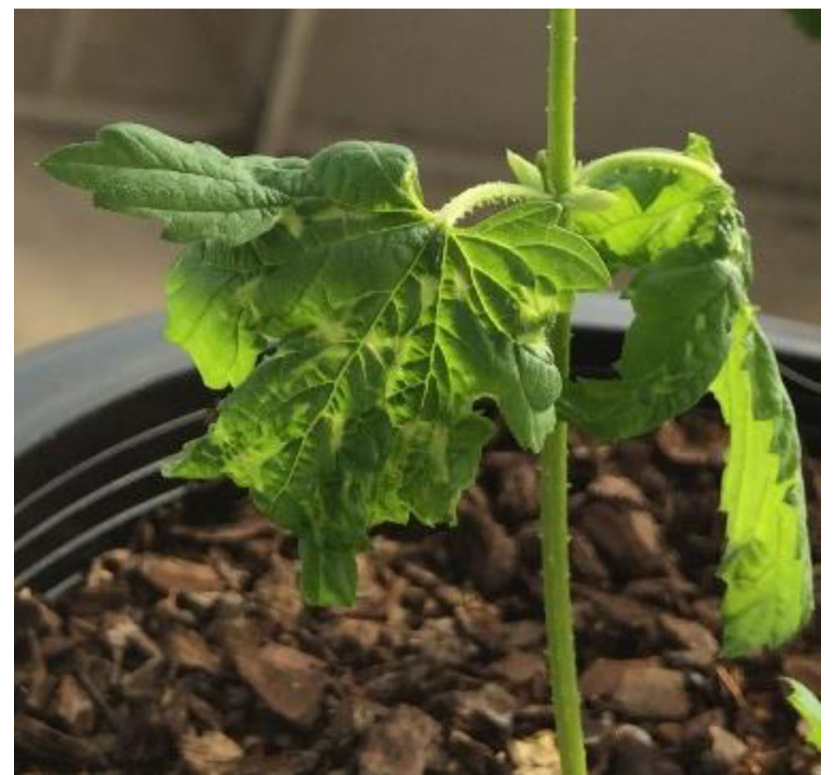

Fig. 1 Leaf symptoms of HSVd infected hop at time of sampling

both commodities were grown. This report confirms the presence of HSVd in hop plants in Australia. Hop plants are grown to support the brewing industry; the cones they produce contain organic acids to add bitterness to beer. HSVd can cause significant reduction in cone yields and alter the ratio of organic acids ( $\alpha$-acid and $\beta$-acid) produced in the cones. Symptom expression can vary with cultivar. HSVd reportedly reduces cone yield in cv Cascade but not the production of organic acids (Kappagantu et al. 2017). Asymptomatic HSVd infected cultivars survive as a source of inoculum (Kappagantu et al. 2017) for additional infections. Further research is needed to examine the impact of HSVd infection on brewing quality of hops.

To our knowledge, this is the first host record of HSVd in hops in Australia. Given the prevalence of HSVd in hops overseas, and the limited surveillance and testing of hops in Australia, the viroid may have been present, albeit undetected, in hops in Australia for an extended time. This report emphasises the need for a certification scheme to ensure high health status plant material is available to industry to establish new plantings and maximise productivity.

Acknowledgments The authors gratefully acknowledge support from the NSW Department of Primary Industries.

\section{References}

Bernad L, Durán-Vila N (2006) A novel RT-PCR approach for detection and characterization of citrus viroids. Mol Cell Probes 20(2):105-113. https://doi.org/10.1016/j.mcp.2005.11.001

Crowle DR, Pethybridge SJ, Leggett GW, Sherriff LJ, Wilson CR (2003) Diversity of the coat protein-coding region among Ilarvirus isolates infecting hop in Australia. Plant Pathol 52:655-662. https:// doi.org/10.1046/j.1365-3059.2003.00918.x

Crowle DR (2010) Molecular variation of viruses infecting hops in Australia and associated studies. Doctoral dissertation, University of Tasmania

Dann AL, Hössel SE, Cross PA, Wittock SP (2014) Phylogenetic analysis of American hop latent virus in Humulus lupulus surveyed in Tasmania and Victoria. Australia Australas Plant Dis Notes 9:140. https://doi.org/10.1007/s13314-014-0140-3

Eastwell KC, Nelson ME (2007) Occurrence of viroids in commercial hop (Humulus lupulus L.) production areas of Washington State. Online. Plant Health Prog https://doi.org/10.1094/ PHP-2007-1127-01-RS

Eastwell KC, Sano T (2009) Hop Stunt. In: Compendium of Hop Diseases and Pests p 48. Eds: WF Mahaffee, SJ Pethybridge, DH Gent. American Phytopathological Society, St. Paul, MN

Gillings MR, Broadbent P, Gollnow BI (1991) Viroids in Australian citrus: relationship to exocortis, cachexia and citrus dwarfing. Aust J Plant Physiol 18(5):559-570

Guo L, Lui S, Wu Z, Mu L, Xiang B, Li S (2008) Hop stunt viroid (HSVd) newly reported from hop in Xinjiang. China Plant Pathol 57:764

International Hop Grower's Convention (2020) Economic Commission - Summary Reports. San Carlos de Bariloche, Argentina https:// www.usahops.org/img/blog_pdf/293.pdf

Kappagantu M, Nelson ME, Bullock JM, Kenny ST, Eastwell KC (2017) Hop Stunt Viroid: Effects on Vegetative Growth and Yield of Hop Cultivars, and Its Distribution in Central Washington State. Plant Dis 101(4):607-612. https://doi.org/10.1094/ PDIS-06-16-0884-RE

Kinoti WM, Nancarrow N, Dann A, Rodoni BC, Constable FE (2020) Updating the quarantine status of Prunus infecting viruses in Australia. Viruses 12:246. https://doi.org/10.3390/v12020246

Koltunow AM, Krake LR, Rezaian MA (1988) Hop stunt viroid in Australian grapevine cultivars: potential for hop infection. Australas Plant Path 17:7-10. https://doi.org/10.1071/APP9880007

Lee JY, Lee SH, Sanger HL (1990) Viroid diseases occurring on Korean hop plants. Korean J Plant Pathol 6(2):256-260

Lin CY, Wu ML, Shen TL, Yeh HH, Hung TH (2015) Multiplex detection, distribution, and genetic diversity of Hop stunt viroid and Citrus exocortis viroid infecting citrus in Taiwan. Virol J 12:11 https://doi.org/10.1186/s12985-015-0247-y

Munroe D (1987) Viruses infecting hop, Humulus lupulus, in Australia. Aust J Agric Res 38:83-90

Radisek S, Majer A, Jakse J, Javornik B, Matoušek J (2012) First Report of Hop stunt viroid Infecting Hop in Slovenia. Plant Dis 96(4):592. https://doi.org/10.1094/PDIS-08-11-0640-PDN

Sasaki M, Shikata E (1977) On some properties of hop stunt disease agent, a viroid. Proc Jpn Acad Ser B 53:109-112

Wang X, Zhou C, Tang K, Zhou Y, Li Z (2009) A rapid one-step multiplex RT-PCR assay for the simultaneous detection of five citrus viroids in China. Eur J Plant Pathol 124:175-180. https:// doi.org/10.1007/s10658-008-9386-y 